\title{
Exploring and Evaluating the Niche of Social Work as an Engine of Social Development in Selected African Countries
}

\author{
Prof. S. M Kang'ethe \\ University of Fort Hare, Department of Social Work and Social Development \\ Box X1314, Alice, 5700, South Africa \\ Email: skangethe@ufh.ac.za
}

\section{Doi:10.5901/mjss.2014.v5n23p1734}

\begin{abstract}
The article, through a systematic literature methodology, endeavours to evaluate and debate the role of social work as an engine of social development in selected African countries. Findings indicate that social work can achieve the following aspects of social development: Encourage philanthropy as a strategy to address various individual vulnerabilities; facilitate participation of the grassroots communities in socio-economic development of their geographical areas; offers psycho-emotional services to release stress and desperation; urge and advocate for the spirit of volunteerism and service to others. On the other side of the coin, Social work in some African countries appears to display the following flaws: It continues to follow a curriculum that was crafted by the western world countries that does not adequately match the growth needs of African countries; It is not adequately addressing most of the social illnesses African countries are experiencing; It is professionally not adequately conspicuous and is usually eclipsed by other professions such as sociology, psychology, economic etc. The article recommends that: social work curriculum be reconfigured, re conceptualized, re indigenized to address local problems; shed its western component and be augmented to address the challenges of the African countries; is adequately remunerated to match other professions to avoid apathy workforce attrition; given an opportunity by the government to play an active role in administration, economics and leadership position.
\end{abstract}

Keywords: Social Work curriculum, vulnerabilities, social ills, apathy, social work inconspicuity, poverty

\section{Problem Statement}

Undeniably, although social work as a growing and younger discipline is increasingly being recognized globally in dealing with various vulnerabilities, it is pertinent that its role in the social and economic terrain is discussed, debated so that such growth factors can be strengthened and any possible motivation and any other positive addendum identified to strengthen the professional pursuit of the discipline. On the other side of the coin, perhaps its snail's pace growth and its degree of inconspicuity amidst other sister professions such as psychology and sociology need to be unearthed and recommendations to address them possibly brought to the fore. Such an analysis, this researcher believes will put the profession on a balance and possibly prompt forces that will see its growth escalates.

\section{Methodology}

This is a literature review article that has prompted debates, discourses and discussions pertaining to the role of social work as an engine of social and economic development; as well as looking at the other side of the coin to underpin several of the challenges the discipline suffers. The article has benefited from eclectic sources of literature from journals, books etc and this researcher's experiential intuition

\section{Social Work as an Engine of Social and Economic Development}

\subsection{Social work and philanthropy}

Undeniably, social work is a welfare based profession meant to look into issues that impede people's social functioning and enhancement of their well being generally (Zastrow \& Kirst-Ashman, 2013). Since poverty reduction and mitigation remains some of the social work goals, social work cannot run away from promoting factors that, albeit for a little while, act upon poverty and other ramifications surrounding the state of poverty factors driving (Sheafor \& Horejsi, 2008; Segal, 
Gerdes \& Steiner, 2007). This is why social workers and social work profession generally welcome the principle of philanthropy to facilitate the transfer of resources from those who are well endowed in the society to the less privileged. Define ably, philanthropy connotes "love of humanity", caring for the needy, embracing and sharing love with those loved little, feeling for one another and normalizing the tenet and principle of sharing. Viewed broadly, philanthropy fulfils the desires and goals of many religious sacred literature that stand for sharing and being kind to one another (Kang'ethe \& Rhakudu, 2010). In a way, philanthropy sends the message to the indigent and less privileged that that there are some people out there who are ready to feel pain with those in pain and parting with their treasures and resources for the public good. However, this is through the tools of love, empathy and for many being guided by the dictates of religious obligations for those well endowed to consider helping the indigent, the widows, the orphans etc (MacArthur, 2013; Kang'ethe \& Rhakudu, 2010). Philanthropy may not only be expressed through giving charity and resources, but also volunteering to give services to the needy (Kang'ethe, 2010; Rankopo, Osei-Hwedie \& Moroka, 2006). The celebrated and winner of Nobel peace price for her work of charity in 1979, the late, Mother Teresa of Calcutta (1910-1997) was an embodiment of philanthropy in that she gave all she had in terms of human resource to help the needy. In fact, she perfected the tenet and principle of golden rule that espouses doing good to the others, being selfless and kind (Kang'ethe \& Rhakudu, 2010). For example people bedridden at home under the auspice of community home based care programmes in most African countries need the societies' philanthropic disposition. They need someone to cry with them, to wipe them their tears, to socially engage with so that they may find life a bit more treasurable (Kang'ethe , 2006).

Besides social work impetus to drive the phenomenon, philanthropy has been strengthened and driven by individuals with bigger hearts and also by faith based organizations. It is this researcher's believe that although social work uses its tools of advocacy, lobbying and brokerage to reach out to the wealthy and the influential who can donate or influence the well endowed with resources to donate and consider the welfare of the vulnerable groups, it should be in every individual's heart to help as much as one can, especially those surrounding oneself and those who are needy (Trevithick, 2005). This is because sometimes the vulnerable population needs the R20 in one's pocket without any critical budget allocation for their meal, or they sleep hungry. This means that with the love and a little bit of effort, many people who consider themselves not well endowed can be philanthropic and make a difference in other people's lives (Mac Arthur, 2013).

\subsection{Facilitate grassroots participation and involvement}

Perhaps one of the achievements of social work is its emphasis on empowering the local grassroots community members to get involved and participate in their development endeavours (Lombard, 1009). This role it achieves through the use of its constellations of skills such as consultative, lobbying, advocacy, empathy, discussions, brainstorming, etc (Trevithick, 2005). This is to strike and enhance ownership of such programmes and projects (Lombard, 1991). This is upholding and bolstering the principles of community development that espouses community participation, consultation, and ownership of all the development endeavours in the community. This is why social work emphasizes on social and economic development programmes that are bottom- up instead of being top-bottom. This is because although some developments have to be initiated by the policy makers at the echelon of governance, they need to be explained to the people so that the general populace gives them the blessings and support. Involving people at the grassroots and facilitating their participation is a panacea in that it makes people to understand the development from their own lenses. However, although social work strives to achieve these, sometimes top- bottom approach to development has not allowed this kind of participation and involvement. Perhaps this is why there are many discontents and strikes in South Africa where the people do not feel adequately involved and respected by the governance structures (Kang'ethe 2014; Dhai, Etheredge, Vorster \& Veriava, 2011).

\subsection{Social work concerned with psychosocial welfare}

Social work facilitates psychosocial empowerment in that people need to be bolstered psychologically, and their social well being needs to be strengthened. This is because the quality of people's lives is determined by their psychosocial disposition and engagements. This means attending to social stresses, relations, poverty, individual employability and physical environments in which people live. When these negative social factors take huge toll on the lives of the people, then their psychosocial well being is bound to be compromised. It is therefore the mandate of social work profession to endeavour to address these environments that are counterproductive to psychosocial well being (Zastrow \& KirstAshman, 2013; Sheafor \& Horejsi, 2008; Segal, Gerdes \& Steiner, 2007). Perhaps it is important for the author to expound the environment of most African settings and circumstances that usually compromise the communities' 
psychosocial well being. Taking the case of children in most communities, if they cannot go to school at the right age simply because the granny who lives with them after the parents died of HIVIAIDS or other diseases, they may feel left out of place and despondent. If they can go to sleep without filling their stomach, if their small grass thatched roof is blown off by strong winds and the granny is not strong enough to fix the roof timeously, or there are no relatives nearby to hear their cry, if strong rains cannot allow children to cross the poorly logged bridge and make the way to school, if children's father usually come very drank and molests them, if their parents are quarreling and arguing all the time, such children are likely to experience a state of apathy, despondency, anxiety and desperation. Then they can only score sparingly in the psychosocial scale (Trevithick, 2005). Lets now turn to a mother living in a squalid environment: if she has to take the nurturance role alone because the husband abandoned her, if she is underemployed and getting very little money to afford the basics, if in the event of having a partner, he is not responsible and always quarreling with her and molesting the children, this then would present an environment that puts such a woman to experience a very low state of psychosocial well being (Nurses Association of Botswana (NAB), 2004; Uys \& Cameron, 2003). For a man who is either unemployed, or is underemployed, and if employed is only on a time on task employment status and struggling to meet the needs of his children, with the environment of a nagging wife who threatens to leave because of his meager resources, with an environment in which children ask for money to meet their basic needs which he does not have, being in an environment that he is neither recognized nor respected by both the wife and the children as well as his in laws and his own parents, of course because he has not been able to raise dowry for them, and for his parents, he is not able to treat them handsomely even during Christmas, then such a man is likely to experience apathy in life, suffer a state of disillusionment and disenchantment, and can even experience suicidal tendencies. This presents a state of low psychosocial well being (Trevithick, 2005; Sheafor \& Horejsi, 2008; Segal, Gerdes \& Steiner, 2007).

Although social workers may not have answers to the myriad social and economic problems that most individuals especially from poor societies experience, these are the circumstances they endeavour to address in the world of meager resources

\subsection{Social work facilitates Volunteerism and service to one another}

In an African setting, even before the development of the current social work discipline, social work existed informally through communities advocating and emphasizing on cooperation, embracing the principle of one being "his/her brother's/sister's keeper", staging work parties in which societies helped one another in building houses and attending to the farms together. This in Botswana was called molaletsa (Rankopo, Osei-Hwedie \& Moroka, 2006). This ensured equality and equity because even the weaker were assisted to grow with the others. The societies, therefore, had social work safety nets in which individual problems were addressed by the larger society. The social work culture was also embraced through the spirit of volunteerism (boithaopo in Setswana language- lingua franca for the country of Botswana). Although today, the processes of globalization, modernization, civilization and eurocentrism have had a huge toll in dismantling most African cultures and social work based activities (Kang'ethe, 2009, 2013), still social work ethos of societal members helping one another especially the indigent is still in place, although people appear to increasingly adopt individualism as opposed to collectivism. In embracing individualism, people first take care of their challenges and problems before they turn to their neighbours, and sometimes they never care what their neighbours undergo (Nicholas, Rautenbach \& Maistry, 2010). This author needs to be sincere to indicate that most societies such as Botswana and South Africa continue to experience the dwindling spirit of volunteerism and collectivism (Kang'ethe 2006, 2010). These is acting counter the social work values of empathy, being of service to one another and being able to settle conflicts and bring peace and tranquility. This in South Africa made the former President, Thabo Mbeki in 2002 call for societies to strengthened their spirit of volunteerism to especially those in need. In Botswana, the spirit of social work volunteerism is glaringly conspicuous with a horde of both informal and formal volunteers aiding the community home based care projects in virtually all the corners of the country (Kang'ethe 2010; Rankopo, Osei-Hwedie \& Moroka, 2006).

\section{Social Work Flaws}

\subsection{Poor remuneration}

Perhaps this is one of the issues that has put down the profession of social work, or thwarted its growth compared to other disciplines such as the psychology, sociology etc (Kang'ethe, 2014). Remuneration is key to the growth of a profession. In many African countries, social work professionals have had a raw deal in that they are not paid as much as other professions such as economists. This has made many social workers to go to western countries where the 
profession is adequately recognized and well remunerated (Department of Labour, 2008; Kang'ethe, 2014).

\subsection{Social work follows a western centric curriculum}

A score of researchers including this researcher have increasingly voiced their concern and a possible bottleneck that the discipline of social work faces in Africa, that of having a curriculum that is crafted for the western countries. This has made some interventions not to work because of the nature of the problems that are largely influenced by the geographical locale. This is why many scholars such as Osei Hwedie, Mupedziswa and Kang'ethe (Osei-Hwedie, 1993, 1996; Mupedziswa, 1992, 2005; Kang'ethe 2014) are advocating for a culturally relevant social work curricula that should consider the geographical locale, cultures of the people and their indigenous knowledge systems (Kang'ethe, 2011)

\subsection{Social work not adequately addressing most of the African's social ills}

According to Morales, Sheafor and Scott (2011), social work is a profession of many faces, a versatile profession, and it is also generally viewed as a helping profession that utilizes professionally qualified personnel who apply a repertoire of skills and knowledge packages to help tackle their social problems (Mupedziswa, 2005). However, it is increasingly been challenged by the dynamics of development and emergence of some social ills and diseases such as HIVIAIDS, SARs etc. For example when HIVIAIDS emerged in the 80 's, many social workers took time to understand the dynamics associated with HIVIAIDS (Barnett \& Whiteside, 2006). It took some times to have the message get internalized and embraced by the social workers especially the generalist social workers without any advanced clinical diagnosis skills (Maguire, 2002). However, the fact that societies believe it is the social workers who are supposed to address people's social problems put them in a fix for people could not understand why social workers could not handle the challenge expeditiously (Kang'ethe, 2014).

\subsection{Social work Suffers professional inconspicuity}

Undeniably, although social work is still growing and societies are increasingly recognizing its importance especially in handling social ills and their ramifications, it is a fact that it is a profession that is not glaringly conspicuous and appears to be in the background of other professions (Kang'ethe, 2014). Perhaps this is because it has borrowed much of its literature from other established disciplines such as sociology, psychology and other social sciences (Kang'ethe 2014). Perhaps also the governments have not given the profession all the recognition and dignity it deserves as a helping profession. Perhaps also the fact that it is also associated with vulnerabilities of various kinds put it as a profession that is vulnerable. It is therefore critical that the social workers themselves work to give it the mileage and honour it deserves by performing sterling tasks that will catch the attention of the governments and other professions. It needs to move in tandem with other professions such as sociology, perhaps through research and notable milestones to communities and the world at large (Kang'ethe 2014)

\section{Recommendations}

Social work curriculum should be reconfigured, re conceptualized, re indigenized to address local problems; shed its western component and be augmented to address the challenges of the African countries; is adequately remunerated to match other professions to avoid work apathy; given an opportunity by the government to play an active role in administration, economics and leadership position.

\section{Conclusion}

Social work plays a critical role in addressing the challenges of poverty and different kinds of vulnerabilities. This researcher contends that analyzing and highlighting the social work role as an impetus to social and economic development is pivotal to making the profession be recognized and its status highlighted. Importantly, social work should therefore attract recognition from the governments and its people. It should be adequately be remunerated and social workers should be motivated to raise the status of the profession so that it may achieve the same recognition and dignity as its sister professions. 


\section{References}

Barnett T \& Whiteside A 2002. AIDS in the Twenty-First Century. Disease and Globalization. Hampshire: Palgrave Macmillan.

Department of Labour (2008). Social Work as a scarce and critical profession. Scarce \& Critical Skills Research Project. A research commissioned by the Department of Labour, South Africa.

Dhai, A., Etheredge, H.R., Vorster, M. \& Veriava, Y. (2011 ). The public's attitude towards strike action by healthcare workers and health services in South Africa. SAJBL December 2011. Vol 4, No2.Page 58-62.

Kang'ethe, S.M (2006). Contribution of caregivers in community home based care programmes. The case of Kanye, Botswana. Unpublished Phd Dissertation in the faculty of Social sciences, North West University, South Africa

Kang'ethe S.M (2009). Traditional healers as caregivers to HIVIAID patients. Sahara journal. Vol. 6 (2). September, 2009. Pp.83-91.

Kang'ethe, S.M (2010). Exploring states of panacea and perfidy of family and community volunteerism in palliative care giving in Botswana. Indian Journal of Palliative Care. Jan-Apr 2010/Vol 16/Issue-1. Pp 15-22.

Kang'ethe, S.M (2011). Evidences of indigenous knowledge systems driving care giving in care programmes in Botswana. Fort Hare Papers. Vol 18, 2011. Pp 5-15.

Kang'ethe, S.M (2013). The panacea and perfidy of cultural rites of circumcision in African countries: Examples from Kenya, Botswana and South Africa. EASSRR Journal. Vol. xxix, no 1, pp. 107-123.

Kang'ethe, S.M (2014). Exploring social work gaps with examples from South Africa and Botswana: In the press of Journal of Social Sciences.

Kang'ethe , S.M \& Rhakudu, M (2010). Exploring Religious Education. Heinemann. Gaborone, Botswana Lombard, A. (1991). Community work and community development: Perspectives on social development, Haum Tertiary, Pretoria.

Mac Arthur, J (2013). The MacArthur Study Bible. NKJV. Revised and Updated. Thomas Nelson. New York

Morale, A.T., Sheafor, B.W. \& Scott, M.E (2011). Social Work. A profession of Many Faces. 12th edition. Allyn \& Bacon. Boston, London, Sydney \& Toronto.

Maguire,L.(2002). Clinical Social Work. Beyond Generalist Practice with Individuals, Groups and families. Brooks/Cole. Thomson learning. Australia, Canada. Mexico. Singapore.

Mupedziswa, R. (1992). 'Africa at the crossroads: major challenges for Social Work Education and Practice towards the year 2000' in Journal of Social Development in Africa, Vol. 7, No 2.

Mupedziswa, R. (2005). Challenges and prospects of social work services in Africa. In J.C. Akeibunor \& E.E Anugwon (Eds). The social sciences and socio-economic transformation in Africa (pp271- 317). Nsuka: Great AP Express Publishing.

Nicholas, L., Rautenbach, J.,\& Maistry, M. (2010). Introduction to social work. Capetown. Juta Nurses Association of Botswana (NAB) (2004). Caring for the Caregivers. Gaborone, Kgotla Designs PTY LTD, Botswana.

Osei- Hwedie, K. 1993. 'The challenge of social Work in Africa. Starting the indigenization Process'. Journal of Social Development in Africa (1993), 8,1, 19-30.

Osei-Hwedie K .(1996). "The indigenisation of Social Work Practice and Education in Africa: the Dilemma of Theory and Method" Social Work/Maatskaplike Work, 32 (3): 215-25.

Rankopo, M.J., Osei-Hwedie,, K. \& Moroka, T.M (2006).Issues in service and volunteerism in Botswana. VOSESA. Page 24-38.

Segal, E.A, Gerdes, K. E \& Steiner, S. (2007). An introduction to the profession of Social Work. Becoming a change agent. Second edition. Thomson. Brooks/Cole.

Sheafor, B. W. \& Horejsi, C. R. ( 2008). Techniques and guidelines for Social Work Practice. Allyn \& Bacon. Boston, London, Sydney \& Toronto.

Trevithick, P. (2005). Social Work Skills and Knowledge. A practice Handbook. Open University Press, Maidenhead, England.

Uys, L \& Cameron, S. (2003). Home Based HIVIAIDS Care. Cape town. Oxford University

Zastrow, C. H \& Kirst-Ashman, K.K. (2013). Introduction to Social work and social welfare. New York. Cengage Learning 